\title{
TRUTH, RESPONSIBILITY AND THE POLITICAL. JAN PATOČKA'S VIEW ON LIVING IN TRUTH ${ }^{1}$
}

\section{WING-KEUNG CHIK}

PhD candidate, Catholic University of Louvain, Institut Supérieur de Philosophie, 1348 Louvain-laNeuve, Belgium.

E-mail: louischik@gmail.com

Being one of the spokespersons of the civic manifestos Charta 77, Czech Philosopher Jan Patočka (19071977) passed away after repeating interrogation. For human dignity, Patočka stands himself in truth in front of violence. What is the origin of responsibility which resists injustice? ${ }^{2}$ What is the significance of living in truth for being confronted with violence? In the text of Charta 77 «The Obligation to Resist Injustice» (1977), Patočka points out that morality of humanity is the ground of obligation. ${ }^{3}$ Then, what is the relationship between humanity and moral obligation? Regarding to the question above, this paper attempts to investigate the relationship of responsibility and living in truth, and demonstrates that there is an ontological responsibility of insistence implicated in living in truth, through illustrating the structure of manifestation of problematization. Socratic care of soul is the practice of familiarizing citizens with problematization through reflective dialogue as pluralization of otherness (doxai) of others. Otherness unveiled is the beginning of thinking and of the formation of polis. At last, with the analysis of worldliness of world as manifestation of plurality, the article will show that the responsibility of living in truth, as responding to plurality of world and realizes problematization which reforms community as polis with liberation and unity, is philosophical-political revolutionary.

Key words: Care of the soul, problematization, responsibility, Arendt, otherness, dialogue, thinking, polis, pluralization.

1 This article is dedicated to Prof. Kwok-Ying LAU (The Chinese University of Hong Kong), and to the prodemocratic Umbrella Movement of Hong Kong (2014).

2 This is the title of one of the texts of Charta 77 of Patočka, «The Responsibility to Resist Injustice»(1977) (Kohák, 1989, 340-343).

3 «Yet the point of morality is to assure not the functioning of a society but the humanity of humans. Humans do not invent morality arbitrarily, to suit their needs, wishes, inclinations, and aspirations. Quite the contrary, it is morality that defines what being human means» (Kohák, 1989, 341).

(C) WING-KEUNG CHIK, 2016 


\section{ИСТИНА, ОТВЕТСТВЕННОСТЬ И ПОЛИТИЧЕСКОЕ. ЖИЗНЬ В СОГЛАСИИ С ИСТИНОЙ СОГЛАСНО ЯНУ ПАТОЧКЕ 4}

\section{ВИНГ КОНГ ЧИК}

$\mathrm{PhD}$, Католический Университет Лёвена, Институт философии, 1348 Лёвен, Бельгия.

E-mail: louischik@gmail.com

Будучи одним из представителей гражданского манифеста Хартия 77, чешский философ Ян Паточка (1907-1977) скончался после очередного допроса. Паточка, оставаясь верным самому себе и истине перед лицом насилия, тем самым даёт нам пример человеческого достоинства. Откуда же происходит ответственность, восставшая против несправедливости?5 Каково значение жизни в согласии с истиной и в конфронтации с насилием? В тексте Хартии 77 «Обязательство сопротивления несправедливости» (1977), Паточка показывает, что мораль человечности основа такого обязательства. ${ }^{6}$ Как же взаимосвязаны человечность и моральное обязательство? Отталкиваясь от данного вопроса, эта работа ставит перед собой задачу изучить взаимосвязь между ответственностью и жизнью в согласии с истиной, а также показать на примере структуры проблематизации, что онтологическая ответственность настойчивости такого рода имплицитно присуща жизни в согласии с истиной. Сократическая забота о душе - это практика ознакомления граждан с проблематизацией через рефлексивный диалог как плюрализацию инаковости (doxai) других. Инаковость является началом размышления и формирования полиса. Наконец, благодаря анализу суетности мира как манифестации плюральности, статья должна показать, что ответственность жизни в согласии с истиной, являясь ответом на плюральность мира и пониманием пробематизации, реформирует сообщество и превращает его в полис, который имеет потенциал освобождения и объединения, а потому является философско-политически революционным.

Ключевые слова: Забота о душе, проблематизация, ответственность, инаковость, диалог, мышление, Арендт, полис, плюрализация.

\footnotetext{
4 Эта статья посвящена профессору Квок-Ину Китайского университета Гонконга, а также продемократическому «Движению зонтиков» Гонконга (2014).

5 Это название одного из текстов Хартии 77 Паточки «The Responsibility to Resist Injustice» (1977) (Kohák, 1989, 340-343).

6 «Все же моральность должна гарантировать не успешное функционирование общества, но человечность людей. Люди не изобретают мораль произвольно, с целью удовлетворения своих потребностей, желаний, склонностей и стремлений. Наоборот, мораль - это как раз то, что определяет человеческое в человеке» (Kohák, 1989, 341).
} 
Independent initiatives address the hidden sphere; they demonstrate that living within the truth is a human and social alternative and they struggle to expand the space available for that life; they help even though it is, of course, indirect help - to raise the confidence of citizens; they shatter the world of «appearance» and unmask the real nature of power.

The Power of the Powerless - To the memory of Jan Patočka, Václav Havel

\section{INTRODUCTION}

The article is composed of two main parts:

Firstly, it will be demonstrated that responsibility is ontologically implicated in living in truth as problematization, through elucidating the structure of manifestation. Secondly, it will be shown that Socratic care of the soul is the practice of problematization with others that familiarizing others to participate in or to share with living in problematicity in which otherness as doxai of others are being revealed. The revelation of otherness of others is the pluralization of otherness among citizens that letting the invisible otherness become visible. The cultivation of unveiling otherness of others as pluralization of doxai is the preparation of polis as ordinary way of practicing co-problematization.

In the second part, it will be elucidated that otherness or difference unveiled in dialogue is the beginning or happen of thinking. Thinking as internal soundless dialogue implies the dependence of the appearance of otherness (in the form of doxai) of others. And then it will be illustrated that polis is not the community of apparent sameness but the mutual-dependence and mutual-encouragement of engaging in coproblematization as practicing manifestation of «not-yet» through revealing otherness in reflective dialogue. Living in truth as the form of polis - mutual encouragement of engaging in the practice of manifestation of being as co-problematization which responds to appearing plural doxai of world - is thus philosophical-political revoltary in its essence. 


\section{LIVING IN TRUTH AND RESPONSIBILITY}

\section{1) Existence as Movements}

In The Natural World and the Movement of Human Existence (1936)7 and the lectures on Body, Community, Language, World (1968-1969), ${ }^{8}$ Patočka characterizes human existence as three kinds of movement. Movement shown by Patočka ${ }^{9}$ has the ontological character of creating or coming-into-being. ${ }^{10}$ The movement of human existence signifies the activity in which humankind brings itself into existence or comes to its life. The first movement of human existence is the elementary and instinctualaffective activity (Patočka, 1998, 143) which attaches to or depends on the bio-physical supply, like care and nourishment. Through the instinctual-affective activities, like the warmth and protection given by others (Patočka, 1998, 149), humankind comes into existence as living on earth. In the first movement, the earth manifests itself as power (Patočka, 1998, 149) which takes over humankind by supplying the need of living. ${ }^{11}$ The earth is the foundation of existence as providing condition of living in the way of domination. Thus there is no freedom in the first movement (Patočka, 1998, 150).

The second movement of human existence is the activity of extending or securement of living, for the instance, working. Through working, humankind exerts to guarantee the necessities of living by production like farming. The activity of farming, as a kind of labour, transforms natural resources into product. Thus the second movement

\footnotetext{
7 Mainly in the part of «Meditation sur "Le Monde naturel comme problème philosophique"» and «Qu'est-ce que l'existence?» (Patočka, 1988).

8 Mainly in the sixteenth lecture "Care and the Three Movements of Human Life» and the seventeenth lecture «The Three Movements of Human Life (continued)» (Patočka, 1998).

9 The notes of Jan Patočka are published as Papiers Phénoménologique [Phenomenological Papers] (Patočka, 1995). (in French).

10 «Signification ontologique - passage du non-être à l'être et inversement par ailleurs: devenir ceci ou cela, cela, c'est-à-dire passer du non-être-à-l'être-quelque-chose, n'est possible que par le mouvement. Le mouvement est donc ce qui rend l'étant ce qu'il est. C'est le mouvement qui unifie, entretient la cohésion, synthétise les déterminations de l'étant. La persistance, la succession des déterminations à même un substrat, etc., sont des mouvements.» (Patočka, 1995, 31)

11 For Patočka, the earth is not only understood as the power of domination, but also as manifestability of being of world. The relevant elucidation will be shown in the part II «Responsibility of Living in Truth as Response to Plurality of World.» (Patočka, 1988, 149)
} 
also attaches to the earth in the way of transformation, i.e., the activity of labour. The second movement is necessary and compulsory to the existence since it enforces the rooting of existence into earth and thus secures the conditions of living. As being alienated activity, ${ }^{12}$ the second movement is the existence without freedom.

\section{2) Movement of Breakthrough: Truth and Freedom}

The third movement of human existence is the activity of breakthrough (Le mouvement de percée) (Patočka, 1988, 118). This movement is an action which attempts to break the domination of acceptance (Patočka, 1998, 159-160).

The third movement does not signify an existence independent of earth, nor derived from previous movements, but hidden or suppressed by previous movements, for example, suppressed by the necessity of working which is understood as the activity of gaining the living for everyday life. The third movement does not detach from world but the meanings given as conventional acceptance. The third movement overcomes the domination of previous movements in the way of questioning or reflection. To reflect or question means distanciating with thematic object as transcendence. In this sense, the activity of reflection surpasses the domination of object through putting it into question. The transcendence of questioning as surpassing revolts the unexamined acceptance of conventional practice and gives rise to alternative. For example, the question «Why the citizens do not have the right of nomination in election?» shakens the conventional norms of not having the right of nomination as accepted necessity. As Paul Ricoeur (19132005) shows in the preface of the French edition of Heretical Essay in the Philosophy of History (1975), ${ }^{13}$ the third movement of human existence as the movement of truth distinguishes itself from the acceptance of predominant normative convention and opens

\footnotetext{
${ }^{12}$ Alienation is understood as inauthenticity of human existence. «This movement, too, has its distinctive mode of inauthenticity, a failure to understand oneself, blinding others and oneself linked to the situation of conflict, suffering, guilt - a blindness, necessarily imposed on others and ourselves, that would not see such things.» (Patočka, 1998, 151)

${ }^{13} 1981$ French edition, Essais hérétiques sur la philosophie de l'histoire, traduit par Erika Abrams, Lagrasse, Verdier, 1981; 1996 English edition, Heretical Essays in the Philosophy of History, translated by Erazim Kohák, edited by James Dodd, with Paul Ricoeur's Preface to the French Edition, Open Court, Carus Publishing Company, 1996.
} 
to manifestation of being. ${ }^{14}$

Questioning is an activity with power which de-solidifies or quakes the conventional practice accepted as norms. Quaking conventional practice does not signify being skeptical to world or falling into nihilism, since questioning does not detach from world but re-forms or renews the relationship with world ${ }^{15}$ by struggling against the domination of normative convention. ${ }^{16}$ Practiced in the form of philosophy, questioning steps forward to not-yet meaning or the being-of-unknown-yet which is on the way of manifesting, ${ }^{17}$ i.e., bringing not-yet being into existence as actualization (e.g., questioning as exploration). With the activity of questioning and reflection, alternative possibilities, which are against the domination of conventional practices, are to be alighted.

14 «The third fundamental movement of life is the movement of truth which, still within the world of prehistory, attests to the difference between the natural and that which is above nature, thus discerns within divinity the possibility of being open, of openness.» (Patočka, 1996, xii)

15 «As a result, meaning will never be simply given or won once and for all. It means that there emerges a new relation, a new mode of relating to what is meaningful; that meaning can arise only in an activity which stems from a searching lack of meaning, as the vanishing point of being problematic, as an indirect epiphany. If we are not mistaken, then this discovering of meaning in the seeking which flows from its absence, as a new project of life, is the meaning of Socrates's existence. The constant shaking of the naive sense of meaningfulness is itself a new mode of meaning, a discovery of its continuity with the mysteriousness of being and what-is as a whole.» (Patočka, 1996, 60-61)

${ }^{16}$ As shown by Etienne Tassin, living in problematicity does not refuse world as solid soil («sol ferme») but resists to accept given meaning taking as granted by shaking meaning of world («sens du monde»). «S'inscrire dans la problematicité, c'est adopter une "attitude qui ne ferme plus les yeux sur les expériences négatives, mais élit domicile à l'intérieur d'elles", et envisager de "vivre dans le déracinement". Penser et agir depuis le déracinement, depuis l'ébranlement du sens du monde et non sur le sol ferme, sera aussi, paradoxalement, ce qui permettra à la philosophie de s'élever contre le relativisme des valeurs et des normes - cela tout en reconnaissant l'historicité fondamentale de l'être humain et la relativité de son orientation au sein du monde ambiant, la relativité de sa science et de sa praxis, des images qu'il se fait de la vie et du monde.», 'La question du sol; Monde naturel et communauté politique', Etienne Tassin, Jan Patočka: Philosophie, Phénoménologique, Politique, textes réunis par Marc Richir et Etienne Tassin (Tassin, \& Richir, 1992, 171). The distinction of staying on solid soil or solid ground (sol ferme) and uprooting (déracinement) of meaning given, and philosophy happens as praxis on the distinction of the two, will be further discussed in next paper.

17 «Thus the result of the primordial shaking of accepted meaning is not a fall into meaninglessness but, on the contrary, the discovery of the possibility of achieving a freer, more demanding meaningfulness. - This is then linked to that explicit awe before being as a whole, the awe-full realization that the totality of being $i s$, which, according to ancient philosophers, is really the inmost pathos and origin of philosophy. Humans who do not remain in the humility of passively accepted meaning cannot be content with their fated lot and fundamentally linked with that is also that new possibility of relating to being and meaning which consists not in a predetermined, preaccepted answer but in questioning, and that precisely is philosophy. Questioning, however, presupposes the experience of mystery, of problematic being and this experience, which prehistoric humankind avoids, from which it takes refuge in the most profound, truth-laden myths, unfolds in the form of philosophy. Just as in acting politically humans expose themselves to the problematic nature of action whose consequences are unpredictable and whose initiative soon passes into other hands, so in philosophy humans expose themselves to the problematic being and meaning of what there is.» (Patočka, 1996, 63) 
Questioning and reflection is the problematization which discloses possibility of being $^{18}$ in the way of suspending the given necessity of normative guidance. Problematization is living in truth. For truth, as primordially understood as disclosure (a-letheia), it is not the knowledgeable judgment coherent with reality, but the activity of manifestation itself on which knowledge is formed. In the article «Life in Balance, Life in Amplitude» (1939) (Patočka, 2007a, 32-42), living in truth is characterized as the «life in amplitude». The «life in amplitude» is the existence which struggles to protest against the enclave of acceptance (Patočka, 2007a, 37-38). The protest discloses possible being of existence and the unknownness of world ${ }^{19}$ which manifests in "wonder». ${ }^{20}$ Problematization is prior to various possible modes of life since it is the existence which searches for different modes of living. Not similar to stone, humankind discovers and realizes possible existences ${ }^{21}$ as self-creation (Patočka, 2002, 209). Living in problematization, i.e., living in truth, as liberating from the veil accepted as selfevident (Patočka, 2007b, 56) and discloses possible existence, is characterized as the new life or rebirth of human existence. ${ }^{22}$ The new life of human existence is the foundation of all possible modes of life since conventional judgements ${ }^{23}$ and various modes of living are being examined and existential choices could be disclosed. Living in truth as problematization is the struggle which acts to overcome the domination of normative and alienated guidance ${ }^{24}$ and realizes the freedom of humankind (Patočka, 2007a, 40).

\footnotetext{
${ }^{18}$ The possibility of being includes both the possible human existence and the being of world. For example, raising the question of «the goal or destination of life» shakens both the way of existence and the meaning accepted as convention.

19 The unknowness of world is the being of world as manifestation of worldliness of world. This will be elucidated in Part II «Responsibility of Living in Truth as Response to Plurality of World».

${ }^{20}$ In the lecture «The Spiritual Person and the Intellectual» (1975), Patočka describes the experience of living in amplitude or problematicity as «wonder». «We wonder: to wonder means not to accept anything as self-evident, to stand still, to stop oneself, not to go further in one's quest, to stop functioning.» (Patočka, 2007b, 55)

${ }^{21}$ Patočka emphasizes, the possibility of existence is not same as the possibility of thing, like the possibility of a cup is for drinking, the activity of drinking actualizes the possibility of the cup as tool of drinking. Instead, the possibility of existence of human is the realization of its own existence. Human life self-realizes itself in its existential possibilities (Patočka, 1998, 146).

${ }_{22}$ «Because in this, in the struggle for freedom, in the struggle with himself, man took possession of himself, of the deepest that he has in himself or that he is able reach. In this spark this new life appears to him.» (Patočka, 2007a, 40)

${ }^{23}$ Thus truth as disclosure of being is prior to formation of judgment (Patočka, 1988, 261).

${ }^{24}$ «La lutte est en ce sens ancrée dans le fond même de l'homme - non pas la lutte comme mode de l'auto-aliénation, mais une lutte qui se rapporte au contraire de cette aliénation et à son dépassement. Car la vie humaine n'est
} 
As we know, problematization examines and revolts conventional guidance, and discloses possible ways of living. With the reflective examination of problematization, conventional practices could no longer be regarded as normative necessity. In other words, another possibility of not-being-as-such (which does not follow normative guidance) is manifested. The being manifested is not temporally belonged to present or past, but future. It is because questioning discloses the possibility which is not-yetto-be-completely-realized. The possibility disclosed is always on the way or the path (cheminement) (Patočka, 1988, 40) of realization. The being of possibilities is yet to be completely realized and is in the process of coming-into-being. The coming-into-being is «still-yet-to-be» or «not-yet-to-be». Questioning, as the activity of problematization which exposes the being of «not-yet-to-be», is always on the way of manifesting the being to be realized and thus it is temporally futural.

The activity of problematization like reflective questioning, always manifests the being of possibility which is yet to be realized completely or yet to come into its being completely. The being of possibility is always on the way of realization. Thus the being of possibility has the ontological character of «not-yet-to-be». The «not-yet-to-be» is existentially belonged to the one who undergoes the activity of problematization. In other words, the being «not-yet-to-be» is owed to the existence of problematization. The being «not-yet-to-be» manifests itself as the task-to-be-finished which is to be realized as redeeming. The activity of problematization is the infinite process of manifesting the being «not-yet-to-be». Thus, the existence of problematization, i.e., activity of disclosure of being, is ontologically responsible for the process of realization of the being manifested ${ }^{25}$ which has the essential character of «not-yet-to-be». Therefore there is an ontological

\footnotetext{
jamais donnée; dans sa figure véritablement humaine, elle doit toujours être conquise, et le mouvement de cette conquête consiste à surmonter, il est une lutte.» (Patočka, 1988, 11)

${ }^{25}$ «I brought your attention to the most important idea, to the formation of the soul itself by itself. This means that this soul turned the experience that it does not know, the experience of knowing its not knowing, into experience about its own being. At the same time, it also experienced that it is brave because it exposed itself to problematization, that it is wise in knowing not knowing in the form of temperate and disciplined investigating, because it submits all other human affairs to this thinking struggle. It is just by making its own what is binding for it, nothing other that, as we would modernly say, its own responsibility; it does not claim anything apart from what is in this way its own.» (Patočka, 2002, 93)
} 
responsibility implicated in the activity of problematization as the being-insistence of the struggle of breaking through the domination of accepted convention. In face of difficulty or adversity, the courage of insistence of problematization, like raising challenging question in front of threat, is the responsibility of realization of the being «not-yet-to-be». The being «not-yet-to-be», as essentially belonged to the existence of problematization, is obligated to be realized as part of the existence. Courage as rooted in «looking-in», is the responsibility in resolution of realizing manifestation. ${ }^{26}$

\section{RESPONSIBILITY OF LIVING IN TRUTH AS RESPONSE TO PLURALITY OF WORLD}

\section{1) Socratic Care of the Soul and Polis}

According to Patočka, ${ }^{27}$ Socrates is the one who insists in problematization through practicing the care of the soul. The soul is not the substance or reality of world. Also the soul is not the "mind» of duality of the distinction of mind and body, but the activity of manifestation or disclosure of being. Care of the soul is the cultivation or activation of manifestation of being. In other words, the care of the soul is the realization of the third movement of human existence. ${ }^{28}$

\footnotetext{
${ }^{26}$ Courage is grounded on the manifestation in problematization which is the activity of «looking-in» as the disclosure of being. "When they risk life, they have to be courageous above all. But what does it mean to be courageous? You see that justice first wants something other than this excellence of the soul: it wants courage of these combatants, it wants a class of people who feel they are on the battlefield in every moment, and in every moment they really are upon it. But courage in Plato is naturally not blind courage, rather it is something regulated through looking-in. To be courageous means to know when I have to risk my life and when I have to threaten others.» (Patočka, 2002, 118)

${ }^{27}$ Not only Patočka, Michel Foucault (1926-1984), in his lectures at the Collège de France (1983-84) on The Courage of the Truth, has shown that Socrates is the one who practices care of the self along his life in Athens. Moreover, the research of Foucault shows that Socratic care of the self is different from Platonic care of self (Foucault, 2011, 95-176). The Socratic care of the self as concerning the existence or life (bios) which is shown in Laches; The Platonic care of the self as establishing the soul being the reality of world as in Alcibiades. Meanwhile, Patočka distinguishes the difference between Socratic attitude and the Platonic attitude to philosophy. The Socratic attitude is the participation of the activity of problematization in public or among citizens. The Platonic one withdraws from the public and builds up the metaphysical kingdom (Patočka, 2007b, 59)

${ }^{28}$ In his Caring for the Soul in a Postmodern Age: Politics and Phenomenology in the Thought of Jan Patočka, Edward F. Findlay suggests that care for the soul is the struggle against the domination of convention and reveals the possibility of freedom as resistance of staying in given meanings accepted once and for all. «What is it that characterizes Greek philosophy in such a distinctive way? Patočka describes it as a conscious decision no longer
} 
As we know, through verifying or examining the oracle of Delphi, ${ }^{29}$ Socrates is not the one who knows everything or possesses definite truth, but the one who knows that he does not know (Platon, 2002, Apology, 21d). Socrates is not satisfied with the living given or goodness accepted as convention, and he acts with examination to search for what he does not know yet. The quest of Socrates demonstrates an alternative of living which is contrary to the life unexamined, is the life in quest (Patočka, 2007b, 54-55).

The Socratic examination, as reflective questioning and discourse, i.e., the activity of manifestation of being, is practiced with others. Socrates situates himself and the interlocutor in problematization, in which living in truth as unveiling of being is awakened and shared among with citizens. According to Hannah Arendt (1906 - 1975), Socrates is the figure who engages in public affairs with philosophical reflection. For Arendt, Socratic practice of problmatization is different from Plato. ${ }^{30}$ Socrates does not rule the citizens by absolute Truth (Arendt, 2005, 15) but familiarizes citizens with living in problematicity. ${ }^{31}$ In the words of Arendt, the practice of Socrates among citizens is

to accept life and its inevitable decline as simply given. Greek philosophy, he contends, is characterized by a challenge, a refusal to accept the simple fate of a world and a life ever in decline. It resisted the inevitability of decline and, in doing so, discovered human freedom and its relation to the eternal. The battle against the degenerative tendency of the world, the resistance to it, is precisely human freedom; this is what the Greeks called care for the soul.» (Findlay, 2002, 59) Michael Gubser regards the epoch of ancient Greek is characterized as practicing problematization as inquiry for truths. «The Greeks recognized world problematicity - the notion that the world is not a fixed presence but an open question — and celebrated human inquiry, establishing insight and responsibility as moral standards. This recognition, said Patočka, launched the historical age, for history was nothing else but the openness to being and the consequent questing for truth.» (Gubser, 2013, 165)

${ }^{29}$ As we have known, given by the oracle of Delphi, Socrates has been told that he is the wisest person of Athens. But Socrates did not listen to the oracle blindly and he acts to verify the message through dialoguing with citizens.

${ }^{30}$ "When Plato claimed rulership for the philosopher because he alone could behold the idea of the good, the highest of the eternal essences, he opposed the polis on two grounds: first, he claimed that the philosopher's concern with eternal things did not put him at risk of becoming a good-for-nothing, and second, he asserted that these eternal things were even more "valuable" than they were beautiful.» (Arendt, 2005, 10)

${ }^{31}$ Socrates practices care of the soul with fellow citizens as familiarizing citizens with the existence of problematization which reveals truths from doxai. The Socratic practice of problematization among with citizens is the pluralization of visibility of citizens (plurality of citizens) through revealing hidden doxai as visible truths. Ivan Chvatík shows that Socrates familiarizes fellow citizens with shaking hidden followed conventional guidance and leads their «soul to tell for itself good from evil». «Socrates in turn mercilessly analyzes everything that had till then been taken for granted, viewed as certain, unchanging and clear, not in order to relativize it, but rather to show, through dialogue with his fellow citizens, where they are going wrong, misunderstanding or contradicting themselves in their views on the good conduct of life. He who contradicts himself is empty, hollow, i.e., actually inexistent, though he hides this from himself through empty discourse. Socrates shames those he confutes, but gives no advice; faithful to his "non-knowing", he endeavors to lead their soul to tell for itself good from evil.» (Chvatik, 2011, 269) According to Martin Palouš, familiarizing citizens with problematization re-builds polis by correlating polis to the activity of philosophy that may overcome the decadent crisis of ancient Athens. «We all 
to «make friends» with citizens (Arendt, 2005, 16) by sharing citizens with a possible existence which is liberated from accepted domination of conventions.

With regards to citizens, Socrates does not teach definite truth or does not teach what he possesses; instead, Socrates claims that he knows nothing but knowing that he does not know. According to the interpretation of Arendt, the claim of Socrates means that he does not know the opinions or doxai of others, ${ }^{32}$ and thus Socrates unveils others' doxai and turns doxai be seen as appearing in public. ${ }^{33}$ In the words of Arendt, Socrates reveals doxa «in its own truthfulness». Revealing doxa «in its own truthfulness» is to let doxa stand up on its own among other doxai in the face of others, by turning doxa into truth in the way of revealing doxa from hidden accepted guidance to become distinct from other doxai through questioning and dialogue. In this sense, revealing doxai of others is to unveil otherness or the difference of others. For example, raising the question «What does it mean by democracy?» reveals democracy as the political system of state which is distinct from other systems like aristocracy and monarchy by bringing it closer in illustration. In clarification, democracy is other than or different from aristocracy and monarchy. During questioning and dialogue, doxa is being examined by ridding of contradiction as truthfulization that brings doxa into light which is distinct from other doxai, i.e., to be appearing itself among other doxai. Socrates regards himself as practicing midwifery that generates knowledge, i.e., truths, from doxai of citizens. ${ }^{34}$

recall the exchange, in the Apology, between Socrates and his accusers concerning the problem of the education of youth. Who is a good educator and, on the contrary, who corrupts the young? In Ancient Athens, the polis itself was held to be the best educator, but what happens, then, in times of crisis? Is the best teacher still the mass of law-abiding citizens, the polis as a whole, with its dubious customs and decadent culture, or rather the philosopher? Socrates' answer to this question, and the verdict of the Athenians, are well known. From that point on, polis and philosophy went their separate ways.» (Palouš, 2011, 172)

32 «For mortals the important thing is to make doxa truthful, to see in every doxa truth and to speak in such a way that the truth of one's opinion reveals itself to oneself and to others. On this level, the Socratic "I know that I do not know" means no more than: I know that I do not have the truth for everybody; I cannot know the other fellow's truth except by asking him and thereby learning his doxa, which reveals itself to him in distinction from all others.» (Arendt, 2005, 19)

${ }^{33}$ "To assert one's own opinion belonged to being able to show oneself, to be seen, and heard by others. To the Greeks this was the one great privilege attached to public life and lacking in the privacy of the household, where on is neither seen nor heard by others.» (Arendt, 2005, 14)

34 «Socrates, who refused public office and honor, never retired into this private life, but on the contrary moved in the marketplace, in the very midst of these doxai, these opinions. What Plato later called dialegesthai, Socrates himself called maieutic, the art of midwifery: he wanted to help others give birth to what they themselves thought 
Socrates wanted to bring out this truth which everyone potentially possesses. If we remain true to his own metaphor of maieutic, we may say: Socrates wanted to make the city more truthful by delivering each of the citizens of their truths. The method of doing this dialegesthai, taking something through, but this dialectic brings forth truth not by destroying doxa or opinion, but on the contrary by revealing doxa in its own truthfulness. The role of philosopher, then, is not to rule the city but to be its «gadfly», not to tell philosophical truths but to make citizens more truthful. The difference with Plato is decisive: Socrates did not want to educate the citizens so much as he wanted to improve their doxai, which constituted the political life in which he too took part. To Socrates, maieutic was a political activity, a give-and-take, fundamentally on a basis of strict equality, the fruits of which could not be measured by the result of arriving at this or that general truth. (Arendt, 2005, 15)

Emphasized by Arendt above, the Socratic practice of philosophy does not aim to rule the city or the citizens by seeking ultimate or eternal Truth as Plato does but makes citizens be visible through revealing doxai of citizens as visible truths in front of others through reflective dialogue. In revealing doxai of citizens as visible truths, it is the process of pluralization that unveils or articulates hidden doxai of citizens to be visible opinions among themselves. The pluralization of doxai of citizens $s^{35}$ as revelation of otherness or alternative is the refusal to the dominance of conventional norms since pluralization is processed as revealing doxai of citizens through examination as problematization which revolts against or transcends accepted guidances. ${ }^{36}$ Hence, Arendt considers Socratic dialogue is political in nature. «The purging element in thinking, Socrates' midwifery, that brings out the implications of unexamined opinions and thereby destroys them values, doctrines, theories, and even convictions - is political by implication.» (Arendt, 2003, 188)

anyhow, to find truth in their doxa.» (Arendt, 2005, 15)

${ }^{35}$ The process of pluralization of doxai of citizens may respond the question raised by Martin Palouš that problematization as pluralization of doxai may give account to the political phenomenon of plurality as fundamental aspect of human condition. «Nonetheless, in going through all his references to her analyses and observations, not only in the final text of the Heretical Essays, but also in the preparatory manuscripts and lectures from this period, I was puzzled by his total silence as concerns Arendt's central point: human plurality as an essential aspect of our human condition, neglected by Western political philosophy. How can he have accepted some of her greatest insights, while at the same time closing his eyes to core elements of the revolution she wrought in contemporary political thinking?» (Palouš, 2011, 170)

36 «The quest for meaning, which relentlessly dissolves and examines anew all accepted doctrines and rules, can at every moment turn against itself, as it were, produce a reversal of the old values, and declare these as "new values".» (Arendt, 2003, 177) 
Through revealing doxai as truths through questioning and dialogue, doxai stand up themselves in face of others. Doxai are revealed as difference among citizens. Dialogue does not cancel difference but reveals differences among interlocutors, ${ }^{37}$ i.e., revealing doxai, which are different from the others, to be visible to interlocutors or adversaries. Through dialogue, interlocutors know the thoughts or opinions of others, and the opinions of others could thus be visible to each other. Revealing opinions of others in dialogue is the visualization of the difference or otherness between interlocutors, i.e., visualizing the invisible object which is out of their sight before dialogue. ${ }^{38}$ Doxai unveiled are the otherness of others. Otherness is the beginning or happen of thinking. For Aristotle, wonder is the glimpse of being of thought at the very first time. Thinking begins with wonder. Thinking happens with wonder that thinking is the activity of approaching the good or the being of thought by practicing the unique activity of human being as philosophizing, when knowing that being ignorant in front of being of thought (Aristotle, 2004, Metaphysics, 982b).

In the activity of problematization, world is no longer disclosed as substantial object or the power of dominance, but as interior worldliness of world which is the manifestability ${ }^{39}$ of world. The manifestability of world ${ }^{40}$ discloses itself primordially

\footnotetext{
${ }^{37}$ But the difference between interlocutors manifested in dialogue does not lead to separation; on the contrary, there is a unity of mutual promotion of each other to problematization. The relevant analysis will be demonstrated in later paragraphs.

${ }^{38}$ Not only the hidden doxai as objects of thought are being unveiled, but also the invisible process of thinking as problematization is also visualized by bringing close in dialogue since the appearance of difference or otherness is the origin or the happen of thinking. The elucidation will be showed in the following paragraphs.

39 «L'idée du monde, le monde comme idée, ne sont pas compréhensibles si nous considérons le monde comme un ensemble de données effectivement réelles, mais seulement si nous le concevons comme l'ensemble des données dans leur rapport légal a des potentialités inépuisables qui, bien qu'irréalisables, nous sont a priori ouvertes et donnent sens à chaque expérience actuelle singulière; ces potentialités sont des horizons. (On pourrait dire aussi que chaque chose comporte la sphère de sa "manifestabilité", la sphère de ce dans quoi elle se montre comme étant ce qu'elle est - la sphère de sa phénoménalité; le monde comme horizon de tous les horizons serait alors ce qui donne à chaque chose singulière la possibilité de se montrer).» (Patočka, 1988, 88-89)

${ }^{40}$ In Heretical Essays it is named «phenomenality». Phenomenality does not signify manifestation of particular meaning of beings but the process of manifesting which is the movement of manifestation which alights particular meaning of beings as letting-be-seen. «However, there is also a derivative phenomenality. It does not consist in the self-givenness of something that is, but rather in a showing forth of something that manifests itself of itself; a phenomenality which manifests manifestation and therein secondarily something that manifests itself primarily.» (Patočka, 1996, 8-9)
} 
in the form of interest (inter-être) in natural world or non-problematic world as the community of "gods and mortals» ${ }^{41}$ that invites to come to the being of world ${ }^{42}$ as unveiling the manifestability of world as manifesting. Interest is not worldliness itself, but the path to worldliness as manifesting. Interest discloses itself as givenness of being of world, for an instance, the interest of music. The interest of music invites us to come closer to the manifestation of being by practicing relevant activities, like listening or playing music. Through participating in the activities of interest, the being of world as manifesting is furtherly unveiled.

In Aristotelian sense, there is no growth or actualization of soul if being of world is absent. For Aristotle, actualization of soul is the practice of virtuous activities, e.g., thinking, which approach to manifestation through the activities. In Of the Soul, Aristotle analogizes the object of thinking with the object of sensation, thinking happens when it meets the object of thinking (i.e., being of thought), just like sensing activity happens when sensation reaches its object of sensation, like colors and sound. For Aristotle, human life actualizes itself through practicing unique virtuous activity ${ }^{43}$

${ }^{41}$ "Thus this tradition attests to a prehistorical world of which we can speak as "natural" in the sense just described. It is natural in the sense of accepting the community of all it contains as something simply given, something that simply manifests itself. It is a community of gods and mortals, the shared life-space of those dependent on the nourishing earth and the heavenly lights and of those who are not so dependent and who thus constitute the most wondrous mystery of this world.» (Patočka, 1996, 25)

42 «The nonproblematic world is one in which concealment is not experienced as such. That does not mean that such a world would not have or know secret things, the sacred, or the mysterious; on the contrary, it can be full of such things, they might even play a decisive role - but it lacks the experience of the transition, of the emergence of what-is as phenomenon out of obscurity into the openness in the course of which even that which allows what-is to become manifest shows itself and thereby and only thereby sets questions about what-is on a firm foundation.» (Patočka, 1996, 12)

${ }^{43}$ For Aristotle, friendship is favorable to virtuous person because of the difference between the being of virtuous activity and the person who practices virtuous activity. Owing to finitude of human beings, the being of virtuous activity could not be possessed as beings. Maintaining friendship with the ones who are virtuous par excellence promotes the cultivation of virtuous activities and thus human soul remains being active. With observing virtuous actions and discussion, staying close to virtuous persons is the way of awakening virtuous activities. Maintaining active in soul through practicing virtuous activity, e.g., reflective dialogue, encourages reciprocally to $c o$-self-actualization of virtuous persons. That is the reason why Arendt considers that Aristotle regards friendship as the bondage of polis (Arendt, 2005, 17). This will be discussed in later paragraphs. «Further, it is thought that the happy person must live pleasantly. But the solidary person's life is hard, since it is not easy for him to be continuously active all by himself; but in relation to others and in their company it is easier. [...] Further, good people's life together allows the cultivation of virtue, as Theognis says.» (Aristotle, 1999, 149,1170a) «For we said at the beginning that happiness is a kind of activity; and clearly activity comes into being, and does not belong to [someone all the time], as a possession does. Now if being happy consists in living and being active; the activity of the good person is excellent, and [hence] pleasant in itself, as we said at the beginning; what is 
which approaches - desires ${ }^{44}$ (philia) - the object, e.g., being of thought in thinking, that exceeds soul.

For Arendt, thinking happens as loving (erôs) ${ }^{45}$ about the object which is not present yet, and thus thinking approaches the object of love as movement of wind ${ }^{46}$ or swiftness ${ }^{47}$ that stepping beyond and approaching the not-yet-being. Based on the nature of thinking as moving beyond and approaching the not-yet-being, thinking de-validates conventional norms and accepted values ${ }^{48}$ as shown in problematization. Following Socrates (Platon, 2015, Theaetetus, 189e6-190a7; Sophist, 263e3-5), Arendt regards thinking as internal soundless dialogue with self. Internal dialogue means it is

our own is pleasant; and we are able to observe our neighbors more than ourselves, and to observe their actions more than our own; it follows that a good person finds pleasure in the actions of excellent people who are his friends, since these actions have both the naturally pleasant [features - they are good, and they are his own]. The blessed person, therefore, will need virtuous friends, given that he decides to observe virtuous actions that are his own, and the actions of a virtuous friend are of this sort. Further, it is thought that the happy person must live pleasantly. But the solitary person's life is hard, since it is not easy for him to be continuously active all by himself; but in relation to others and in their company it is easier.» (Aristotle, 1999, 149, 1170a); «We agreed that someone's own being is choiceworthy because he perceives that he is good, and this sort of perception is pleasant in itself. He must, then, perceive his friend's being together [with his own], and he will do this when they live together and share conversation and thought.» (Aristotle, 1999, 150, 1170b)

44 «Every desire, too, is for the sake of something; for it is for the object of desire which is the starting-point of the practical intellect, and the last [step reached by the practical intellect] is the beginning of action. So it is with good reason that these two - desire and practical thought - appear to be the moving causes; for what causes motion is the appetitive [soul], and it is through this that thought causes motion, for the starting-point of [this] thought is the appetitive [soul].» (Aristotle, 1981, 57, 433b)

45 «Socrates calls this quest for meaning erôs, a kind of love which is primarily a need - it desires what it has not and which is the only matter he pretends to be an expert in. Men are in love with wisdom and do philosophy (philosophein) because they are not wise, just as they are in love with beauty and "do beauty", as it were (Philokalein, as Pericles called it) because they are not beautiful. Love; by desiring what is not there, establishes a relationship with it. To bring this relationship into the open, make it appear, men speak about it in the same way the lover wants to speak about his beloved.» (Arendt, 2003, 179)

46 «Socrates himself, very much aware that thinking deals with invisibles and is itself invisible, lacking all the outside manifestation of other activities, seems to have used the metaphor of the wind for it: "The winds themselves are invisible, yet what they do is manifest to us and we somehow feel their approach". (The same metaphor, incidentally, is used by Heidegger who also speaks of the "storm of thought").» (Arendt, 2003, 175)

${ }^{47}$ "As a word, house is shorthand for all these things, the kind of shorthand without which thinking and its characteristic swiftness - "swift as a thought" as Homer used to say - would not be possible at all. The word house is something like a frozen thought which thinking must unfreeze, defrost as it were, whenever it wants to find out its original meaning.» (Arendt, 2003, 172-173)

48 «The consequence of this peculiarity is that thinking inevitably has a destructive, undermining effect on all established criteria, values, measurements for good and evil, in short on those customs and rules of conduct we treat of in morals and ethics. These frozen thoughts, Socrates seems to say, come so handy you can use them in your sleep; but if the wind of thinking, which I shall now arouse in you, has roused you from your sleep and made you fully awake and alive, then you will see that you have nothing in your hand but perplexities, and the most we can do with them is share them with each other.» (Arendt, 2003, 175-176) 
one who raises question and the same one who answers the question. Although thinking as internal dialogue is solidary in nature, thinking is not isolated from others nor isolated from world. Thinking involves necessarily the appearing plural doxai of others. ${ }^{49}$ Thinking happens as endeavor of manifesting along with world that revealing itself as appearing doxai of others which are split from thought or out of thought. The world is not constitution of thinking, but the reality of appearing doxai of others. ${ }^{50}$ Thinking begins or happens as the movement of manifesting which approaches appearing plural doxai of world in the way of revealing doxai as truthfulization. Thus thinking may be solidary, but «not lonely».

For nothing can be itself and at the same time for itself but the two-in-one that Socrates discovered as the essence of thought and Plato translated into conceptual language as the soundless dialogue eme emauto - between me and myself. But, again, it is not the thinking activity that constitutes the unity, unifies the two-in-one; on the contrary, the two-in-one become One again when the outside world intrudes upon the thinker and cuts short the thinking process. Then, when he is called by his name back into the world of appearances, where he is always One, it is as though the two into which the thinking process had split him clapped together again. Thinking, existentially speaking, is a solidary but not a lonely business; solitude is that human situation in which I keep myself company. (Arendt, 1978, 185)

As shown by Arendt above, reality «intrudes» and «cuts short» thinking. Reality shows something, i.e., the otherness of others, which is «more than» thinking or thought. The thinker intruded by reality could ${ }^{51}$ be called by reality to come forward to the

\footnotetext{
${ }^{49}$ «Moreover, while engaged in the dialogue of solitude, in which I am strictly by myself, I am not altogether separated from that plurality which is the world of men and which we call, in its most general sense, humanity. This humanity, or rather this plurality, is indicated already in the fact that I am two-in-one. ("One is one and all alone and evermore shall be" is true only of God). Men not only exist in the plural as do all earthly beings, but have an indication of this plurality within themselves.» (Arendt, 2005, 22)

50 «To Socrates, as to his fellow citizens, doxa was the formulation in speech of what dokei moi, that is, "of what appears to me". This doxa had as its topic not what Aristotle called the eikos, the probable, the many verisimilia (as distinguished from the unum verum, the one truth, on the one hand, and the limitless falsehoods, the falsa infinita, on the other), but comprehension of the world "as it opens itself to me". It was not, therefore, subjective fantasy and arbitrariness, but was also not something absolute and valid for all. The assumption was that the world opens up differently to every man according to his position in it; and that the "sameness" of the world, its commonness (koinon, as the Greeks would say, "common to all") or "objectivity" (as we would say from the subjective viewpoint of modern philosophy), resides in the fact that the same world opens up to everyone and that despite all differences between men and their positions in the world - and consequently their doxai (opinions) — "both you and I are human".» (Arendt, 2005, 14)

${ }^{51}$ Instead of facing or confronting otherness, the one intruded by otherness could flee away from otherness. But fleeing away from otherness is possible on the ground of otherness is being primordially unveiled as fundamental phenomenon of human existence. The problem of fleeing away from otherness and its relationship with evil is
} 
appearance of plurality of doxai. In the lectures on thinking (1951-1952), ${ }^{52}$ by tracing the etymological origin of the meaning of «thinking» and «calling», Heidegger regards thinking as the activity of thanking to the appearing of being of world in which our heart belongs..$^{53}$ "Thanking» is the devotion to what is owed for as being beholden ${ }^{54}$ and gives thought to what it is belonged to.$^{55}$ For Heidegger, interest is not leisure activity but the involvement of being of beings. ${ }^{56}$ "What is called thinking» does not only designate what thinking is but furtherly «what calls for thinking» or «what invites thinking that sets thinking in motion». ${ }^{57}$ Thinking is the activity of thanking that giving back to the appearing ${ }^{58}$ being of world. In the word of Arendt cited above, it is the «One» in which

to be discussed in detail in another article.

${ }^{52}$ Martin Heidegger, lectures on What is Called Thinking?, a translation of Was Heist Denken?, translated and with an introduction by J. Glenn Gray, Perennial, 1976 (Heidegger, 1976).

${ }^{53}$ Here «heart» does not mean the organ of body but the connection or communication with the being of world. "The thanc means man's inmost mind, the heart, the heart's core, that innermost essence of man which reaches outward most fully and to the outermost limits, and so decisively that, rightly considered, the idea of an inner and outer world does not arise.» (Heidegger, 1976, 144)

54 «In giving thanks, the heart gives thought to what it has and what it is. The heart, thus giving thought and thus being memory, gives itself in thought to that to which it is held. It thinks of itself as beholden, not in the sense of mere submission, but beholden because its devotion is held in listening. Original thanking is the thanks owed for being. That thanks alone give rise to thinking of the kind we know as retribution and reward in the good and bad sense.» (Heidegger, 1976, 141)

55 «This thinking which recalls, and which qua thinking alone is true thanks, does not need to repay, nor be deserved, in order to give thanks. Such thanks is not a recompense; but it remains an offering; and only by this offering do we allow that which properly gives food for thought to remain what it is in its essential nature. Thus we give thanks for our thinking in a sense that is almost lost to our language, and, so far as I can see, is retained only in our Alemannic usage. When the transaction of a matter is settled, or disposed of, we say in Alemannic dialect that it is "thanked". Disposing does not mean here sending off, but the reverse: it means to bring the matter forth and leave it were it belongs. This sort of disposing is called thanking.» (Heidegger, 1976, 146)

${ }^{56}$ "Interest, interesse, means to be among and in the midst of things, or to be at the center of a thing and to stay with it.» (Heidegger, 1976, 5)

${ }^{57}$ "In the widest sense, "to call" means to set in motion, to get something underway — which may be done in a gentle and therefore unobtrusive manner, and in fact is most readily done that way. In the older Greek version of the New Testament, Matthew 8:18, we find: "(Sentence in ancient Greek) - seeing a large crowd around him, he called to them to go the other side". The Greek word (word in ancient Greek) properly means to get something on the road, to get in underway. The Greek noun (another word in ancient Greek) means way. And that old word "to call" means not so much a command as a letting-reach, that therefore the "call" has an assonance of helpfulness and complaisance, is shown by the fact that the same word in Sanskrit still means something like "to invite"." (Heidegger, 1976, 117)

58 «Presence does demand unconcealment, and is a rising from unconcealment - though not generally but in such a way that presence is the entry into a duration of unconcealment. The Greeks experience such duration as a luminous appearance in the sense of illuminated, radiant self-manifestation. Continuance is the comingto-the-fore that is at rest, has come to rest before the unconcealedness of what lies before us. Rest in duration is not, however, the absence of movement. Rest, in the presence of what is present, is a gathering. It gathers the rising to the coming-to-the-fore, with the hidden suddenness of an ever-possible absenting into concealness. The 
reality manifests as plural appearance of doxai and invites thinking happens.

Thus philosophical thinking does not separate itself from world; rather, philosophical thinking arises from world, precisely, from the plurality of doxai of world. Existence of problematization, as the activity of self-realization of human beings, is the response to the provocation ${ }^{59}$ of the manifestability of world. The responsibility of living in problematicity, which grounds ontologically on the activity of manifesting, does not separate itself from worldliness of world as manifestability but implicates itself in the response $^{60}$ to appearing plural doxai of world. ${ }^{61}$

(ancient Greek word) in the (another ancient Greek word), the coming into present being and being present, does not mean that what is present comes toward us men as object. The (first ancient Greek word) means nearness, in the sense of the radiance issuing from unconcealedness into unconcealedness. What has come near in such nearness may be very distant.» (Heidegger, 1976, 237)

${ }^{59}$ «La lutte demeure indispensable en tant que lutte de l'éveil. Un tel combat n'est pas initialement une attaque, mais plutôt une provocation à la riposte, aux représailles à l'extermination. C'est seulement dans la défense opposée à cette répression primaire, à la puissance qui alors seulement devient ce qu'elle est, que se produit la révolte. La révolte ne se manifeste pas nécessairement à chaque fois comme violence physique, la violence n'est là que secondairement, en tant que conséquence, encore qu'elle soit étroitement liée au fait que l'éveil est toujours fini. L'éveil est un renouveau, une mise à découvert authentique de la vie, non dans sa profondeur passée et sa donation passive, mais dans l'appel irradie par sa dépendance, appel qui nous somme d'assumer, en y adhérant, ce à quoi, en tant que sort fini, nous ne pouvons échapper, ce qui nécessairement advient, mais qui pour cette raison même nous donne la possibilité de ne pas nous gaspiller, de ne pas nous fragmenter dans tout ce qui tend toujours à détourer notre regard de ce que nous sommes.» (Patočka, 1988, 43-44)

60 "Responsibility» is understood as the duty («have-to») of finishing the task «not-yet-finished». For example, «It is my responsibility to do the housework» means neither out of fondness nor being forced, but the task of «have-to» finish the housework undone; the responsibility of doing housework is grounded on relating the room to cleanness. The «relating» is an infinite process of realization of the demand of cleanness manifested (the room is to be cleaned once it is dirty). The responsibility is grounded on the process of «relating oneself to the manifested». In other word, responsibility is the realization of co-relation of being which relates to existence itself. (Corresponding to the main text we have discussed above, responsibility is implicated in the realization of manifestation of being. The realization of manifestation of being is the process of relating to the being manifested, i.e., the process of realization of corelation to being). «Response» (or «respond») is understood as «answering or action done to that which is relating to oneself», for example, «The teacher has responded my question» means that the teacher has done something, e.g., explanation, to answer the question which is relating to him (since the question is posed to the subject taught by teacher). Response is the action rooted in the discovery (manifestation) of that which is relating to existence, i.e., rooted in manifestation of co-relation. Thus, it is shown that responsibility, as grounding itself on the realization of co-relation of being, is structurally linked to response as manifestation of co-relation. Responsibility, as the activity of co-relation of being to existence, is the realization (the existential capability) of manifestation of co-relation. In short, responsibility is the realization of response. Referring to the main text, interest (interêt: inter-être) is the activity which relates the existence to the being manifested (e.g., interest of music). Response, as the activity which acts to the being related to oneself, is co-relational. Responsibility has implicated itself in the activity of realization of response, i.e., the realization of co-relation of being. Questioning is not the activity of pure detachment or pure de-corelation but re-corelation in the way of de-corelating. Questioning does not direct itself to absolute nothingness but always on the way of unveiling being (as shown in the main text). Thus, responsibility (realization of co-relation) as insistence to response (co-relation of being) is implicated in questioning (as both de-corelation and re-corelation).

${ }^{61}$ In Caring for the Soul in a Postmodern Age: Politics and Phenomenology in the Thought of Jan Patocka, Findlay 
In dialogue or discussion, the others' opinion is to be visualized in sight as being considered during dialoguous discussion. Although dialogue reveals difference or otherness among interlocutors, this does not imply separation between interlocutors. From the perspective of transcendence of existence, reflective dialogue is the mutual encouragement of practicing problematization as spiritual activity of human being, through manifesting the difference or otherness (in the form of doxai) of others which is «outside of» the thoughts of individuals that awakens thinking. In the second essay of Heretical Esssay in the Philosophy of History, Patočka analyses polemos of Heraclitus and emphasizes that polemos as lightning of being unifies the conflicts among interlocutors. It is because polemos is the vision or letting-be-seen which lets interlocutors see or visualize the being of world manifested as otherness in problematization of dialogue. ${ }^{62}$ And thus

states that responsibility is not moral standard beyond existence, but a mode of living (living in quest) which responds to oneself and to «world perceived as a whole». «Responsibility is not a moral value. It has no abstract content. Nor is it an Aristotelian virtue, responding to a sense of proportion or moderation. Instead, it describes the manner of living in which one acts in response to one's own being, as well as to the world perceived as a whole.» (Findlay, 2002, 150)

${ }^{62}$ The interpretation of polemos as revealing difference or otherness with respect to interlocutor in dialogue which promotes problematization is consistent with the interpretation of polemos of Nicolas De Warren as violent renewal of meaning from being, since the revelation of difference is the appearance of «violence» as otherness which is against or exceeds the given thought of interlocutor («being» used by De Warren) as happening of thinking or problematization. «Polemos is the violence of ontological questioning that fractures the apparently seamless bond between meaning and being. [...] The bondage of the natural world is thus two-fold: it is the bondage to a total meaning, not simply as a totality of meaning that defines the world, but as a seamlessness, or lack of differentiation, between "meaning" and "being"; it is the bondage to an unquestionable relation towards being, or, in other words, a forgetting of being. Once grasped in its ontological dimension, polemos is not a violence against meaning per se (for, indeed, violence against meaning pervades the natural world), but against the seamlessness of meaning and being that characterizes the abiding sense in which the pre-given meanings of "what-is" within the natural world are taken for granted, as given without further question and concern.» (De Warren, 2014, 221-222) «In sum, polemos is not equivalent to violence against pre-given meaning without further ontological qualification; it is, moreover, not equivalent to the destruction of meaning and tumble into sheer meaningless. Polemos is a passage, a "flashing forth", through a radical form of questioning and existence.» (De Warren, 2014, 222) James Dodd regards war understood by Patočka as the "archetype» of revolting against meanings given or assigned, and bringing forth new relationship to world. «That is, if profane everydayness, revolting against its own marginalization, has taken on the radicalized form of a selfproduction that feeds on anything that has force; if our understanding of the kind of beings that we are is that we are just given material available for a will to create; then war becomes the very archetype of that moment of a willful break from the given situatedness of life towards a new world, uniquely shaped by force, though for all that essentially bound to the profane.» (Dodd, 2006, 126, italics added) «Without war, individuals tend to slip through the grip of mere life, which without war can be nothing but an empty superficiality in the face of the transcendence of the sacred and the responsible. With war, the grip of mere life becomes total, for 
both interlocutors depend on each other to visualize the being of world as manifesting and thus unity is built among them. ${ }^{63}$ Unity in this sense does not mean holding same opinion among interlocutors, but the mutual encouragement of participating in problematization as manifesting «not-yet» in the visualization of otherness unveiled in dialoguous discussion. Hence, separation does not happen in the process of mutual manifestation of difference or otherness in dialogue; on the contrary, polis is born as new community ${ }^{64}$ with unity which is the mutual-dependence of $c o$-engaging in problematization which shakens accepted normative convention and renews relationship with world. For the formation of community as polis, Arendt regards it as the process of «equalization» of citizens that becoming equal to each other.

threatened life is a seemingly inescapable spiritual trap for those who are addicted to things.» (Dodd, 2006, 128) The interpretation of war of Patočka of James Dodd involves the distinction between sacred and profane, authentic and inauthentic existence of human being, the discussion of the relationship of being of world and generation of meaning as the relation of staying on earth and uprooting of given meanings will be unfolded in the coming article.

${ }^{63}$ «Polemos is not the destructive passion of a wild brigand but is, rather, the creator of unity. The unity it founds is more profound than any ephemeral sympathy or coalition of interests; adversaries meet in the shaking of a given meaning, and so create a new way of being human - perhaps the only mode that offers hope amid the storm of the world: the unity of the shaken but undaunted.» (Patočka, 1996, 43) «Polemos, the flash of being out of the night of the world, lets everything particular be and manifest itself as what it is. Thus the greatest contradiction cleaves together in a unity which is above all, which manifests itself in all and governs all. Humans, however, encounter this One and become wise only when they themselves act, accomplishing their deeds in the atmosphere of freedom ensured by the law of the polis which, in turn, nurtures itself on the one law of the Divine whose name is polemos.» (Patočka, 1996, 43) Findlay shows that polemos as conflict is characterized as the struggle against the domination of given convention in which the unity of community is grounded. «Polemos is the spirit of the polis, by which is meant not the spirit of the Greek polis as a historical event, but the spirit of free politics itself. Conflict, for Patočka, binds the activity of political life to philosophy as the struggle against the fall into an acceptance of given meaning.» (Findlay, 2002, 174) «The unity of a free state is not founded on static ideology but on the struggle against its dominance. It is this commitment to struggle and acceptance of conflict that is the one force to which all parties may equally lay claim.» (Findlay, 2002, 174)

${ }^{64}$ «On this basis there grows a new community and a new way of coming to cognitive terms with the totality of what-there-is. It is a new community, which, to be sure, is no longer simply the work of humans but in which humans do participate freely. It is not only a community of humans with each other, a mutual recognition in which they guarantee each other a spiritual perpetuation in the memory of glory. It is, rather, a community of humans with God who is their eternal memory and the perception of their essential spiritual being. It is a community in which, for all its hierarchy, all humans are equal before the face of the ultimate 'true' reality; in which they are thus true fellow participants in a meaningfulness which they did not create but which they are called to bring about.» (Patočka, 1996, 67) The «mutual recognition» is the encouragement and mutual dependence of each other to participate in realizing a common reality which is the eternal process of truthfulization as breaking through the accepted norms in problematization. «What, though, makes humans just and truthful is their care for their soul. Care for the soul is the bequest of ancient Greek philosophy. Care for the soul means that truth is something not given once and for all, nor merely a matter of observing and acknowledging the observed, but rather a lifelong inquiry, a self-controlling, self-unifying intellectual and vital practice.» (Patočka, 1996, 82) 
If we use Aristotle's terminology in order to understand Socrates better - and great parts of Aristotle's political philosophy, especially those in which he is in explicit opposition to Plato, go back to Socrates - we may cite that part of the Nicomachean Ethics where Aristotle explains that a community is not made out of equals, but on the contrary of people who are different and unequal. The community comes into being through equalizing, isasthenai. This equalization takes place in all exchanges, as between the physicial and the farmer, and it is based on money. The political, non economic equalization is friendship, philia. [...] The equalization in friendship does not of course mean that the friends become the same or equal to each other, but rather that they become equal partners in a common world - that they together constitute a community. Community is what friendship achieves, and it is obvious that this equalization has as its polemical point the everincreasing differentiation of citizens that is inherent in an agonal life. Aristotle concludes that it is friendship and not justice (as Plato maintained in the Republic, the great dialogue about justice) that appears to be the bond of communities. (Arendt, 2005, 17)

«Equal partner» does not only mean ridding of privilege of power among friends or citizens, but the mutual dependence of each other in participating in problematization. In other words, we cannot make dialogue or cannot think as internal dialogue in the condition of absence of Other. As Arendt shows above, community is not made of equals but exactly of difference and unequals. The difference or otherness among citizens is the origin of unifying community as polis in the sense of mutual promoting each other to engage in co-problematization. «Equalization of citizens» is the process of mutualdependence of encouraging each other to participate in co-problematization.

Perhaps we can be inspired from the etymological meaning of the word «dia-

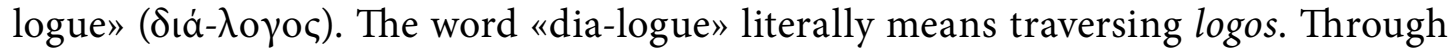
encountering otherness of others, i.e., dialogue as conversation or communication, logos is being traversed or reached in the sense of exercising the spiritual activity of human being. Thinking as internal dialogue, involves otherness (in the form of doxai of others) in itself that otherness awakens thinking. Being internal and soundless, thinking is a modality of dialogue. Polis is the unity of community which practices the ordinary way of thinking as mutual encouragement of engaging in co-problematization among citizens. Thus it could be known that the practice of problematization as Socratic care of the soul promotes the formation of polis by pluralizing doxai among citizens as truthfulization; in this sense, polis is the ordinary way of practicing problematization ${ }^{65}$ among citizens

\footnotetext{
${ }^{65}$ As Findlay shows, polis is the way of practicing problematization as philosophy that promotes the possibility
} 


\author{
through dialogue. Hence Patočka regards Heraclitus observes the «common origin of \\ philosophy and the polis». ${ }^{66}$
}

\title{
CONCLUSION
}

\section{Living in problematicity examines and revolts conventional norms in the way of} transcending ${ }^{67}$ the domination of accepted guidance. Problematization trans-values ${ }^{68}$ the normative guidance from hiddenly accepted to the birth of alternative in disclosure. ${ }^{69}$ The responsibility of living in truth is not the moral code assigned to existence but structurally implicated in problematization as manifesting. In the form of dialogue or

\begin{abstract}
of living in freedom which initiates «rather than simply accept». «The polis was where a philosophy of freedom could concretely manifest itself; it represented the opportunity for the self-aware citizen to reach forth, to no longer merely accept but to actively risk and strive. The polis was both the means to and the symbol of a new human possibility that announced a historical era: the possibility to initiate rather than simply accept.» (Findlay, 2002,99 ) «Politics, then, as conceptualized and epitomized in Socratic philosophy, occupies a higher position in relation to philosophy than either religion or art, for original politics has as its purpose the transmission of philosophical insight to humanity, humanity as a whole and in its most fundamental mode - the mode of its social being. Politics presents us with the possibility to strive for and live a free life. It directly connects the spiritual life to praxis, while religion and art must be largely content with symbolizing that spirituality.» (Findlay, 2002, 109)
\end{abstract}

${ }^{66}$ «Thus Heraclitus sees the unity and the common origin of philosophy and the polis.» (Patočka, 1996, 43)

${ }^{67}$ "Transcendence» is understood as activity of liberating from the domination of normative tradition in the way of quest or reflection. «Socrates' mastery is based on an absolute freedom: he is constantly freeing himself of all the bonds of nature, of tradition, of others' schemata as well as of his own, of all physical and spiritual possessions.» (Kohák, 1989, 180)

${ }^{68}$ «In reality, irony and ambivalence given by the life of Socrates, by the ambiguous meaning of everything he does and says, and this gave meaning and, in turn, from what we could call the transcendence of Socrates. Socrates, on the one hand, and this in the same moral world inhabited by others - also knows its measures and its concepts, know this life is full of it; on the other hand, however, his philosophical idea forced him to give all these concepts a way, to see behind them another dimension, than that in which they move others. With what, and already given the fundamental element of irony, that ambivalence; when Socrates and others think and talk about the good, they do not think and do not say the same thing; and this difference, in turn, on the other hand, is not a mere difference in terminology, because behind it is the trans-valuation of values, that wants to grasp what that man ultimately tends, even if unconsciously, and so you cannot remove the misunderstanding with no other intervention terminology, or other outward.» (translated from Italian) (Patočka, 2003, 399)

${ }^{69}$ For Arendt, instead of following given guidance of convention, thinking practices the capability of telling «right from wrong» that may bring forth caution to «prevent catastrophes». «If thinking, the two-in-one of the soundless dialogue, actualizes the difference within our identity as given in consciousness and thereby results in conscience as its by-product, then judging, the by-product of the liberating effect of thinking, realizes thinking, makes it manifest in the world of appearances, where I am never alone and always much too busy to be able to think. The manifestation of the wind of thought is no knowledge; it is the ability to tell right from wrong, beautiful from ugly. And this indeed may prevent catastrophes, at least for myself, in the rare moments when the chips are down.» (Arendt, 2003, 189) 
internal dialogue as thinking, manifesting happens as responding to plural otherness as doxai of world. Thus the responsibility of living in truth as insistence of manifesting is the response to plurality of world.

Socratic practice of care of the soul as self-creation of existence, reforms community ${ }^{70}$ as polis ${ }^{71}$ with freedom and unity by pluralizing doxai among citizens in the way of revealing otherness vigorously through reflective dialogue. Responding to appearing plural doxai of world, living in truth as unceasing struggle for the revival of community as polis which practices co-problematization and revolts against the domination of conventional guidance with responsibility, is thus philosophicalpolitically ${ }^{72}$ revolutionary.

There are no dangerous thoughts; Thinking itself is dangerous. Hannah Arendt

\section{REFERENCES}

Arendt, H. (1978). The Life of the Mind. New York, NY: Harcourt.

Arendt, H. (2003). Responsibility and Judgment. New York, NY: Schocken.

Arendt, H. (2005). The Promise of Politics. New York, NY: Schocken.

Aristotle, (1981). On the Soul. Grinnell, IA: Peripatetic Press.

Aristotle, (2004). Metaphysics. London: Penguin Classics.

\footnotetext{
${ }^{70}$ «To put it differently, the conflict between philosophy and politics, between the philosopher and the polis, broke out because Socrates had wanted - not to play a political role — but to make philosophy relevant for the polis. [...] Whereas Socrates still obeyed the laws which, however wrongly, had condemned him, because he felt responsible for the city.» (Arendt, 2005, 26)

${ }^{71}$ "The center there is [Greek word], or let us say bravery, the organ of courage, capable of listening to the highest and risking at the same time. In this we discerned what is our soul. Yet, from the cultivating of our soul arises the possibility of forming the state, the community that is necessary so that a person like Socrates does not need to die.» (Patočka, 2002, 121) «You see, then, that the question of the polis and its constitution, its constituting, is again the question of the soul, its character and its examination — care of the soul.» (Patočka, 2002, 121)

72 "The spiritual person is not of course a politician and is not political in the usual sense of this word. He is not a party to the dispute that rules this world - but he is political in yet a different way, obviously, and he cannot be apolitical because this non-self-evident nature of reality is precisely what he throws into the face of this society and of everything that he finds around himself.» (Patočka, 2007b, 63)
} 
Aristotle, (1999). Nicomachean Ethics. Indianapolis, IN - Cambridge, MA: Hackett Publishing Company.

Chvatik, I. (2011). The Responsibility of the "Shaken": Jan Patočka and his "Care for the Soul" in the "Post-European" World. In Chvatík, I., \& Abrams, E. (Eds.), Jan Patočka and the Heritage of Phenomenology: Centenary Papers. Contributions to Phenomenology: Vol. 61 (263-279). Netherlands: Springer.

De Warren, N. (2014). Homecoming. Jan Patočka's Reflections on the First World War.

In Staudigl, M. (Ed.), Phenomenologies of Violence. Studies in Contemporary Phenomenology: Vol. 9 (207-243). Leiden - Boston, MA: BRILL.

Dodd, J. (2006). Violence and Phenomenology. London: Routledge.

Findlay, E. (2002). Caring for the Soul in a Postmodern Age: Politics and Phenomenology in the Thought of Jan Patocka. New York, NY: State University of New York Press. Foucault, M. (2011). The Courage of the Truth (The Government of Self and Others II). Lectures at the Collège De France 1983-1984. Basingstoke: Palgrave Macmillan. Gubser, M. (2013). Jan Patočka's Transcendence to the World. In Copoeru, I., Kono T., Nenon, T., de Haro, A. S., \& Zirión, A. (Eds.), Razón y vida. La responsabilidad de la Filosofía. Investigaciones Fenomenológicas. Revista De La Sociedad Española De Fenomenología [Mind and Life. The Responsibility of Philosophy. Phenomenological Studies. The Spanish Journal of Phenomenological Society]. Monográfico 4/II (155-175). Madrid: Sociedad Española de Fenomenología.

Heidegger, M. (1976). What is Called Thinking? New York, NY: Perennial.

Kohák, E. (1989). Jan Patočka: Philosophy and Selected Writings. Chicago, IL: University of Chicago Press.

Palouš, M. (2011). Jan Patočka's Socratic Message for the 21st Century (Rereading Patočka's “Charter 77 Texts” Thirty Years Later). In Chvatík, I., \& Abrams, E. (Eds.), Jan Patocka and the Heritage of Phenomenology: Centenary Papers. Contributions to Phenomenology: Vol. 61 (163-174). Netherlands: Springer.

Patočka, J. (1988). Le Monde Naturel et le Mouvement de l'Existence Humaine. Dordrecht: Kluwer Academic Pulishers.

Patočka, J. (1995). Papiers Phénoménologique. Grenoble: J. Millon.

Patočka, J. (1996). Heretical Essays in the Philosophy of History. Chicago, IL: Carus Publishing Company. 
Patočka, J. (1998). Body, Community, Language, World. Chicago, IL: Carus Publishing Company.

Patočka, J. (2002). Plato and Europe. Stanford, CT: Stanford University Press.

Patočka, J. (2003). Socrate: Lezioni di Filosofia Antica [Socrates: Lessons of the Ancient Philosophy]. Milan: Bompiani. (in Italian).

Patočka, J. (2007a). Life in Balance, Life in Amplitude. In Manton, E. (Ed.). Jan Patočka: Living in Problematicity (32-42). Prague: Oikoymenh.

Patočka, J. (2007b). The Spiritual Person and the Intellectual. In Manton, E. (Ed.). Jan Patočka: Living in Problematicity (51-69). Prague: Oikoymenh.

Plato, (2002). Five Dialogues: Euthyphro, Apology, Crito, Meno, Phaedo. Indianapolis, IN - Cambridge, MA: Hackett Publishing Company.

Plato, (2015). Theaetetus and Sophist. Cambridge: Cambridge University Press.

Tassin, E., \& Richir, M. (Eds.). (1992). Jan Patočka: philosophie, phénoménologie, politique. Grenoble: J. Millon. 